\title{
PENGARUH KUNJUNGAN WISATA TERHADAP PENDAPATAN MASYARAKAT DI DESA MEDEWI, KECAMATAN PEKUTATAN, KABUPATEN JEMBRANA TAHUN 2012-2015
}

\author{
Selly Ardianti \\ Jurusan Pendidikan Ekonomi, Fakultas Ekonomi \\ Universitas Pendidikan Ganesha Singaraja, \\ Indonesia \\ e-mail: sellysisilya@ymail.com
}

\begin{abstract}
ABSTRAK
Penelitian ini bertujuan untuk mengetahui (1) jumlah kunjungan wisata di Desa Medewi tahun 2016 (2) besarnya pendapatan masyarakat di Desa Medewi tahun 2016 (3) pengaruh kunjungan wisata terhadap pendapatan masyarakat di Desa Medewi tahun 2016. Jenis penelitian ini merupakan penelitian kausalitas. Populasi dalam penelitian ini adalah masyarakat desa medewi yang terkait yaitu Banjar Pesinggahan. Sampel dalam penelitian ini berjumalh 88 orang yang diperoleh dari perhitungan dengan menggunakan teknik proportional random sampling. Teknik pengumpulan data adalah dengan Ttest. Hasil penelitian menunjukan bahwa (1) jumlah kunjungan sebanyak 3.076 pengunjung yang diperoleh dari jumlah tamu yang menginap di hotel-hotel/home stay selama tahun 2016, (2) pendapatan masyarakat adalah Rp.3.000.000 paling rendah dan Rp.40.000.000 paling tinggi perbulannya dan (3) pengaruh kunjungan wisata terhadap pendapatan masyarakat menunjukan bahwa kunjungan wisata tidak berpengaruh terhadap pendapatan masyarakat, karena nilai t hitung pada $p$-value $=0,117>\alpha=0,05$.
\end{abstract}

Kata kunci: desa medewi, objek wisata, pendapatan.

\begin{abstract}
The research aimed to determine; (1) is to know level of visit of tourism object in Medewi in 2016, (2) is to know income of people in Medewi village in 2012-2015, (3) is to know the effect of visit of the tourism object toward the income of people in Medewi village in 2016. This study is a causal research. The population in this study were medewi villagers in Banjar pesinggahan as the area where the tourism object was. The samples used in this study were 88 people which were selected using proportional random sampling. The result of this study shows that (1) the tourism visit as much as 3.076 tourism that stay at hotel/homestay (2) income people is Rp 3.000.000 low and Rp 40.000.000 at the very most by mont and (3) variable of tourism visit affected not significantly toward the income of the people because the value of t-observed $p$-value $=0.117>\alpha=0.05$.
\end{abstract}

Keywords:medewi village, tour object, income. 


\section{PENDAHULUAN}

Keindahan Bali telah sampai ke mancanegara sehingga menjadikannya salah satu destinasi wisata utama di Asia bahkan Dunia. Setiap tahunnya turis mancanegara dan domestik yang berkunjung ke Bali semakin menunjukkan kenaikan yang signifikan. Beberapa objek wisata Bali yang terkenal adalah objek wisata pantai. Salah satu objek wisata pantai yang patut diberikan apresiasi karena keindahannya ialah pantai Medewi.

Pariwisata yang ada di desa Medewi adalah Pantai Medewi (Medewi Beach) dimana terdapat sebuah kekhasan yakni sebuah tanjung pulau yang menyebabkan adanya ombak yang besar dan kemudian dimanfaatkan sebagai tempat olahraga selancar (surfing). Dinamakan Pantai Medewi karena letaknya yang berada di Desa Medewi. Desa Medewi dengan pantainya ini pun semakin berkembang menjadi salah satu destinasi wisata di Bali. Sama halnya seperti fasilitas penunjang tempat wisata menarik di Bali, pantai Medewi sebagai objek wisata menyediakan berbagai fasilitas seperti penginapan, hotel, restoran, toilet umum, kamar mandi, kolam renang dan lahan parkir. Sebagai objek wisata tentunya perlu dilakukan upaya pengembangan demi menarik minat wisatawan baik dalam negeri maupun luar negeri. Usaha mengembangkan dunia pariwisata ini didukung dengan UU Nomor 19 Tahun 1990 dan UU Nomor 10 Tahun 2009 tentang kepariwisataan yang menyebutkan keberadaan objek wisata pada suatu daerah akan sangat menguntungkan, antara lain meningkatkan Pendapatan Asli Daerah (PAD), meningkatkan taraf hidup masyarakat, dan memperluas kesempatan kerja mengingat banyaknya pengangguran saat ini, meningkatkan meningkatkan rasa cinta lingkungan serta melestarikan alam dan budaya setempat (Defi,2012).
Dari sudut sosial, kegiatan pariwisata akan memperluas kesempatan tenaga kerja baik dari kegiatan pembangunan sarana dan prasarana maupun dari berbagai sektor usaha yang langsung maupun tidak langsung berkaitan dengan kepariwisataan. Dari sudut ekonomi bahwa kegiatan pariwisata dapat memberikan sumbangan terhadap penerimaan daerah bersumber dari pajak, retribusi parkir dan karcis atau dapat mendatangkan devisa dari para wisatawan mancanegara yang berkunjung. Adanya pariwisata juga akan menumbuhkan usaha-usaha ekonomi yang saling merangkai dan menunjang kegiatannya sehingga dapat meningkatkan pendapatan masyarakat.

Pendapatan adalah jumlah keseluruhan penghasilan dari pekerjaan utama dan sampingan yang diterima oleh seseorang dalam satu bulan atau satu tahun yang dapat diukur dengan nilai ekonomis, berdasarkan pengukuran ini seorang karyawan dapat digolongkan berdasarkan pendapatan golongan tinggi, sedang dan rendah (Adi :2004). Pengembangan suatu objek wisata yang dilakukan dengan baik akan menghasilkan pendapatan ekonomi yang baik juga untuk komunitas setempat (Joseph D. Fritgen, 1996).

Pembangunan

pariwisata merupakan salah satu pembangunan yang perlu dikembangkan karena dari sektor ini dapat meningkatkan penerimaan devisa negara, menghasilkan pertumbuhan ekonomi yang cepat dalam menyediakan lapangan kerja, peningkatana penghasilan, standar hidup serta menstimulasi faktor-faktor produksi yang lainnya. Oleh karena itu, muncul berbagai kegiatan-kegiatan ekonomi dalam suatu daerah pariwisata seperti hotel, penginapan, biro perjalanan, restoran, industri kerajinan, art shop, serta berbagai fasilitas pendukung lainnya. Keberadaan sektor pariwisata tersebut harus didukung oleh semua pihak yaitu pemerintah, dan masyarakat yang berada 
di kawasan pariwisata serta pihak swasta sebagai pihak penanam modal.

Davidd J. Greenwood dalam Rizal (2000) mengungkapkan bahwa " adanya kunjungan wisata di suatu tempat menyebabkan adanya suatu interaksi sosial antara masyarakat di sekitarnya dengan wisatawan yang dapat mengakibatkan perubahan pola atau tata cara hidup masyarakat. Selain menimbulkan masalah aspek sosial, juga berpengaruh pada aspek ekonomi yaitu terbentuknya peluang atau kesempatan kerja yang dapat meningkatkan pendapatan masyarakat.

$$
\text { Menurut Soekadijo }
$$

pengertian pariwisata adalah segala kegiatan dalam masyarakat yang berhubungan dengan wisatawan. Pariwisata ini menurut Salah Wahab (dalam Pendit, N.S, 1999) adalah salah satu jenis industri baru yang menghasilkan pertumbuhan ekonomi dengan cepat dalam penyedia lapangan kerja, peningkatan penghasilan, standar hidup serta mensimulasi sektor-sektor produktivitas lainnya. Jenis industri baru yang dimaksudkan disini adalah dalam bidang jasa seperti jasa transportasi, jasa akomodasi dan lain-lain, yang mana apabila dikelola dengan professional dan baik akan menghasilkan pencapaian yang ingin dicapai. Sebagai sektor yang kompleks, pariwisata juga meliputi industri-industri kategori yang sebenarnya seperti industri kerajinan tangan, cendramata, transportasi dan penginapan secara ekonomi.

Berdasarkan hasil observasi awal yang peneliti lakukan pada masyarakat desa medewi, adanya objek wisata pantai medewi ini tidak mempengaruhi pendapatan masyarakat. Hal ini dapat dilihat dari semakin banyaknya di bangun hotel dan restoran di kawasan objek wisata pantai medewi tapi tidak menyebabkan pendapatan masyarakat meningkat bahkan cenderung menurun. Hal ini terjadi karena masyarakat tidak banyak dilibatkan dalam industri pariwisata ini.

Bila diperhatikan, orang-orang yang datang berkunjung di suatu tempat atau Negara, biasanya mereka disebut sebagai pengunjung yang terdiri dari beberapa orang dan bermacam-macam motivasi kunjungan termasuk didalamnya adalah wisatawan, sehingga tidak semua pengunjung termasuk wisatawan.

Menurut International Union of Official Travel Organizator (IUOTO), pengunjung yaitu setiap orang yang datang ke suatu negara atau tempat tinggal lain dan biasanya dengan maksud apapun kecuali untuk melakukan pekerjaan yang menerima upah.

\section{METODE}

Penelitian ini dilakukan untuk menguji pengaruh kunjungan wisata terhadap pendapatan masyarakat. Penelitian ini menggunakan jenis penelitian kausalitas yang merupakan bentuk hubungan yang sifatnya sebabakibat, artinya keadaan satu variabel disebabkan, ditentukan, atau dipengaruhi oleh satu atau lebih variabel lain dengan dua variabel, yaitu. 1) Variabel bebas, yaitu variabel yang mempengaruhi atau yang menjadi sebab timbulnya variabel terikat. Yang menjadi variabel bebas penelitian ini adalah jumlah kunjungan wisata (X) dan 2) Variabel terikat merupakan variabel yang dipengaruhi atau yang menjadi akibat, karena adanya variabel bebas. Yang menjadi variabel terikat dalam penelitian ini yaitu pendapatan masyarakat $(Y)$.

$$
\text { Langkah-langkah penelitian }
$$

kausalitas menurut Emzir (2010) penelitian kausal dilakukan dalam lima tahap yaitu. 1)Permasalahan penelitian, 2)Menentukan kelompok yang memiliki karakteristik yang ingin diteliti, 3)Pemilihan kelompok pembanding, 4)Pengumpulan data dan 5)Analisis data.

Populasi dalam penelitian ini adalah masyarakat Desa Medewi yang terkait yaitu Desa Medewi Banjar 
Pesinggahan sebanyak delapan RKA (rukun kipayah) terdiri dari RKA1, RKA 2, RKA 3, RKA 4, RKA 5, RKA 6, RKA7, RKA 8. Rincian populasi pada penelitian ini dapat dilihat pada tabel 1

Tabel 1 Data jumlah masyarakat Desa Medewi Banjar Pesinggahan

\begin{tabular}{ccc}
\hline No & RKA & Jumlah \\
\hline 1 & RKA 1 & 79 \\
\hline 2 & RKA 2 & 91 \\
\hline 3 & RKA 3 & 84 \\
\hline 4 & RKA 4 & 77 \\
\hline 5 & RKA 5 & 93 \\
\hline 6 & RKA 6 & 103 \\
\hline 7 & RKA 7 & 95 \\
\hline 8 & RKA 8 & 86 \\
\hline & JUMLAH & 708 \\
\hline
\end{tabular}

Melihat jumlah masyarakat Desa Medewi Banjar Pesinggahan cukup banyak, maka dari sekian banyak populasi akan diambil sampel. Teknik pengambilan sampel yang digunakan dalam penelitian ini adalah proportionalrandom sampling. Hal tersebut dikarenakan setiap anggota populasi yang ada di dalam rangka sampling mempunyai hak yang sama untuk dipilih menjadi anggota sampel.

Menurut Umar Husein (2005: 78) untuk menentukan jumlah sampel dari suatu populasi dapat digunakan rumus sebagai berikut.

Keterangan:

$$
\text { Rumus } n=\frac{N}{1+N \cdot e^{2}}
$$

$\mathrm{n}=$ ukuran sampel

$\mathrm{N}=$ ukuran populasi

$\mathrm{e}=$ persen kelonggaran ketidaktelitian karena kesalahan pengambilan sampel tang masih ditolerir atau dinginkan, yaitu sebesar $10 \%$.

Berdasarkan rumus tersebut, maka dapat ditentukan jumlah sampel yang akan digunakan dalam penelitian ini. Perhitungan jumlah sampel sebagai berikut.

$$
\begin{aligned}
& N=708 \\
& e=10 \%
\end{aligned}
$$

$$
\begin{aligned}
\mathrm{n} & =\frac{708}{1+708 \cdot(0,1)^{2}} \\
& =\underline{708} \\
& =87.08
\end{aligned}
$$

Setelah dilakukan perhitungan tersebut maka dari jumlah populasi sebanyak 87.6238 (dibulatkan menjadi 88 responden).Sesuai dengan teknik yang digunakan yaitu proportional random sampling maka dapat dilakukan perhitungan besarnya sampel tiap-tiap RKA dari populasi masyarakat Desa

\begin{tabular}{|c|c|c|}
\hline RKA & Jumlah & Sampel \\
\hline RKA 1 & 79 & $\begin{array}{l}79 / 708 \times 88=10 \\
\text { orang }\end{array}$ \\
\hline RKA 2 & 91 & $\begin{array}{l}91 / 708 \times 88=11 \\
\text { orang }\end{array}$ \\
\hline RKA 3 & 84 & $\begin{array}{l}84 / 708 \times 88=10 \\
\text { orang }\end{array}$ \\
\hline RKA 4 & 77 & $\begin{array}{l}77 / 708 \times 88=9 \\
\text { orang }\end{array}$ \\
\hline RKA 5 & 93 & $\begin{array}{l}93 / 708 \times 88=12 \\
\text { orang }\end{array}$ \\
\hline RKA 6 & 103 & $\begin{array}{l}103 / 708 \times 88=13 \\
\text { orang }\end{array}$ \\
\hline RKA 7 & 95 & $\begin{array}{l}95 / 708 \times 88=12 \\
\text { orang }\end{array}$ \\
\hline RKA 8 & 86 & $\begin{array}{l}86 / 708 \times 88=11 \\
\text { orang }\end{array}$ \\
\hline
\end{tabular}
Medewi Banjar Pesinggahan pada tabel 2 sebagai berikut.

Tabel 2 Perhitungan Sampel Masyarakat Desa Medewi Banjar Pesinggahan

Adapun subjek yang digunakan dalam penelitian ini adalah masyarakat desa Medewi yang terkait yaitu yang berada di Banjar Pesinggahan. Sedangkan objek dari penelitian ini adalah variabel-variabel yang diteliti seperti jumlah kunjungan wisata dan pendapatan. Jenis data dalam penelitian ini adalah data kualitatif. Berdasarkan sumbernya, data dalam penelitian ini menggunakan data penelitian sebagai berikut. 1) Data Primer. Data primer dalam 
penelitian ini berupa skor jawaban responden yang diperoleh melalui pengisian koesioner mengenai pengaruh kunjungan wisata terhadap pendapatan masyarakat desa Medewi yang terpilih menjadi sampel. 2) Data Sekunder. Data sekunder dalam penelitian ini berupa dokumen atau catatan dari hasil wawancara terkait jumlah kunjungan wisata di desa Medewi tahun 2012-2015.

Metode pengumpulan data yang digunakan dalam penelitian ini adalah sebagai berikut: 1)Wawancara, Wawancara adalah proses tanya jawab dalam penelitian yang berlangsung secara lisan dimana dua orang atau lebih bertatap muka mendengarkan secara langsung mengenai keterangan-keterangan dan informasi-informasi yang ingin dicari. Adapun yang dapt dijadikan sumber dalam penelitian ini adalah kalangan masyarakat. 2) Dokumentasi, Metode dokumentasi adalah mencari data mengenai hal-hal variabel yang berupa catatan-catatan, transkrip, buku, agenda dan sebagainya.Yang diamati bukan benda hidup tetapi benda mati. Untuk mendapatkan data tentang pengaruh kunjungan wisata yang berupa jumlah pengunjung pada objek wisata di desa medewi.

Setelah data yang terkait dengan masalah dikumpulkan, maka untuk selanjutnya diadakan penganalisisan upaya pemecahan masalah-masalah yang telah dirumuskan sebelumnya. Dalam penelitian ini alat analisa data yang digunakan adalah statistic inference yang betujuan untuk menguji hipotesis dengan menggunakan analisis Uji T test melalui program computer SPSS 16.

Analisis $\mathrm{T}$ test ini digunakan untuk mengetahui besarnya pengaruh kunjungan wisata terhadap pendapatan masyarakat yang perhitungannya menggunakan program SPSS 16. Adapun langkah yang dilakukan dalam Uji $t$ adalah sebagai berikut.

1)Merumuskan Hipotesis. Uji $T$ memerlukan perumusan hipotesis nol $(\mathrm{H} 0)$ dan hipotesis alternatif $(\mathrm{Ha})$. Hipotesis nol dan hipotesis alternatif dalam Uji $\mathrm{T}$ dari penelitian ini adalah sebagai berikut: 1) $\mathrm{Ho}=$ tidak ada pengaruh dari kunjungan wisata terhadap pendapatan masyarakat di Desa Medewi Kecamatan Pekutatan Kabupaten Jembrana tahun 2016. 2) $\mathrm{Ha}=$ ada pengaruh dari kunjungan wisata terhadap pendapatan masyarakat di Desa Medewi Kecamatan Pekutatan Kabupaten Jembrana tahun 2016

2) Melakukan pembandingan antara thitung dengan ttabel (1) Jika thitung lebih besar atau sama dengan ttabel maka hipotesis nihil $(\mathrm{H} 0)$ ditolak, sebaliknya Hipotesis alternatif $(\mathrm{Ha})$ diterima atau disetujui. (2) Jika thitung lebih kecil daripada ttabel maka hipotesis nihil $(\mathrm{HO})$ diterima, sebaliknya Hipotesis alternatif (Ha) ditolak.

3) Merumuskan Dasar Pengambilan Keputusan

Dasar pengambilan keputusan dalam hal ini maksudnya adalah dasar yang digunakan sehingga dapat menetapkan diterima tidaknya hipotesis penelitian. Kemudian, menetapkan taraf signifikansi sebesar 0,05. Lebih lanjutnya dapat dilihat melalui kriteria atau dasar pengambilan keputusan berikut. (1) Jika nilai signifikan $<0,05$ maka $\mathrm{HO}$ ditolak dan $\mathrm{Ha}$ diterima. Hal ini berarti bahwa kunjungan wisata berepengaruh terhadap pendapatan masyarakat di Desa Medewi Kecamatan Pekutatan Kabupaten Jembrana tahun 2016. (2) Jika nilai signifikan > 0,05 maka $\mathrm{HO}$ diterima dan $\mathrm{Ha}$ ditolak. Hal ini berarti bahwa jumlah kunjungan wisata tidak berpengaruh terhadap pendapatan masyarakat di Desa Medewi Kecamatan Pekutatan Kabupaten Jembrana tahun 2016.

Nilai signifikan penelitian dapat diketahui dari hasil pengolahan data dengan SPSS pada tabel Coefficients dalam kolom Sig.

\section{HASIL DAN PEMBAHASAN Hasil}

Hasil penelitian mengenai jumlah kunjungan wisata pada objek wisata 
pantai di Desa Medewi dapat dilihat pada tabel 3

Tabel 3 Jumlah kunjungan wisata pada hotel-hotel/home stay

\begin{tabular}{|c|c|c|c|c|c|c|}
\hline \multirow[b]{2}{*}{ Bulan } & \multicolumn{5}{|c|}{ Nama Hotel/ Home Stay } & \multirow[b]{2}{*}{ Jumlah } \\
\hline & $\begin{array}{l}\text { Medewi } \\
\text { Beach }\end{array}$ & $\begin{array}{l}\text { Brown } \\
\text { Sugar }\end{array}$ & $\begin{array}{r}\text { Point } \\
\text { Village }\end{array}$ & $\begin{array}{c}\text { Sea } \\
\text { Medewi }\end{array}$ & $\begin{array}{l}\text { Medewi } \\
\text { House }\end{array}$ & \\
\hline Jan. & 34 & 36 & 22 & 31 & 16 & 139 \\
\hline Feb. & 51 & 45 & 31 & 20 & 20 & 167 \\
\hline Mar. & 33 & 32 & 28 & 56 & 33 & 182 \\
\hline Apr. & 47 & 41 & 30 & 59 & 45 & 222 \\
\hline Mei & 55 & 28 & 34 & 36 & 28 & 181 \\
\hline Jun. & 58 & 51 & 41 & 34 & 44 & 228 \\
\hline Jul. & 79 & 68 & 52 & 71 & 86 & 356 \\
\hline Agu. & 91 & 74 & 63 & 87 & 113 & 428 \\
\hline Sep. & 84 & 81 & 70 & 42 & 65 & 342 \\
\hline Okt. & 126 & 93 & 52 & 26 & 53 & 350 \\
\hline Nov. & 112 & 89 & 44 & 27 & 29 & 301 \\
\hline Des. & 41 & 39 & 31 & 32 & 37 & 180 \\
\hline Jumlah & 811 & 677 & 498 & 521 & 569 & 3.076 \\
\hline
\end{tabular}

Sumber : Hotel Medewi Beach, Brown Sugar, Point Village, Sea Medewi, Medewi house

Jumlah pengunjung pada setiap bulannya tidak sama, dapat dilihat pada tabel 3 bahwa pada bulan desember hingga juni jumlah pengunjung setiap bulannya kurang dari 300 pengunjung, sedangkan pada bulan juli sampai November jumlah pengunjug setiap bulannya lebih dari 300 orang pengunjung. Hal ini karena dalam kunjungan wisata itu terbagi dalam tiga season yaitu low season, high season, dan fix season. Low season ini merupakan bulan-bulan dimana pengunjung tidak banyak melakukan kunjungan wisata. High season merupakan bulan dimana pengunjung ramai untuk melakukan kunjungan, biasanya high season ini terjadi ketika musim panas (summer) di luar negeri. Fix season merupakan bulan dimana pengunjung tidak terlalu ramai tapi juga tidak terlalu sepi, atau pertengahan antara low season dengan high season.

Hasil wawancara peneliti dengan masyarakat sekitar objek wisata pantai medewi mengenai jumlah pendapatan adalah tergantung dari banyaknya jumlah pengunjung. Jika pengunjung sedikit biasanya pedagang disekitar kawasan objek wisata pantai di Desa Medewi hanya mendapatkan sekitar Rp.100.000-300.000 perharinya dan dalam satu bulan sebesar Rp.3.000.000 - 9.000.000. Apabila pengunjung ramai maka pedagang disekitar kawasan objek wisata pantai Medewi perharinya bisa mendapatkan sekitar Rp.300.000-700.000,- yang berarti perbulannya sebesar Rp.9.000.00021.000.000,-. Pendapatan masyarakat disekitar kawasan objek wisata pantai Medewi ini dapat dikatakan cukup besar karena lebih tinggi dari besarnya Upah Minimum Regional di Jembrana yang besarnya Rp.2.006.000. Pendapatan ini adalah untuk masyarakat sekitar yang berdagang dikawasan objek wisata pantai Medewi. Sebagian besar adalah penjual makanan, camilan dan minuman. Ada juga yang membuka jasa massage dan menyewakan papan surfing.Pengaruh Kunjungan Wisata terhadap Pendapatan Masyarakat

Hasil penelitian tentang pengaruh kunjungan wisata terhadap pendapatan masyarakat di Desa Medewi Kecamatan Pekutatan Kabupaten Jembrana tahun 2016 menggunakan uji $t$ dengan menggunakan program SPSS 16.0 for windows. Hasil tersebut menunjukan bahwa kunjungan wisata berpengaruh 
tidak signifikan terhadap pendapatan masyarakat di Desa Medewi Kecamatan
Pekutatan Kabupaten Jembrana dapat dilihat pada table 4

Tabel 4 Hasil dari uji t dan perhitungan koefisien beta

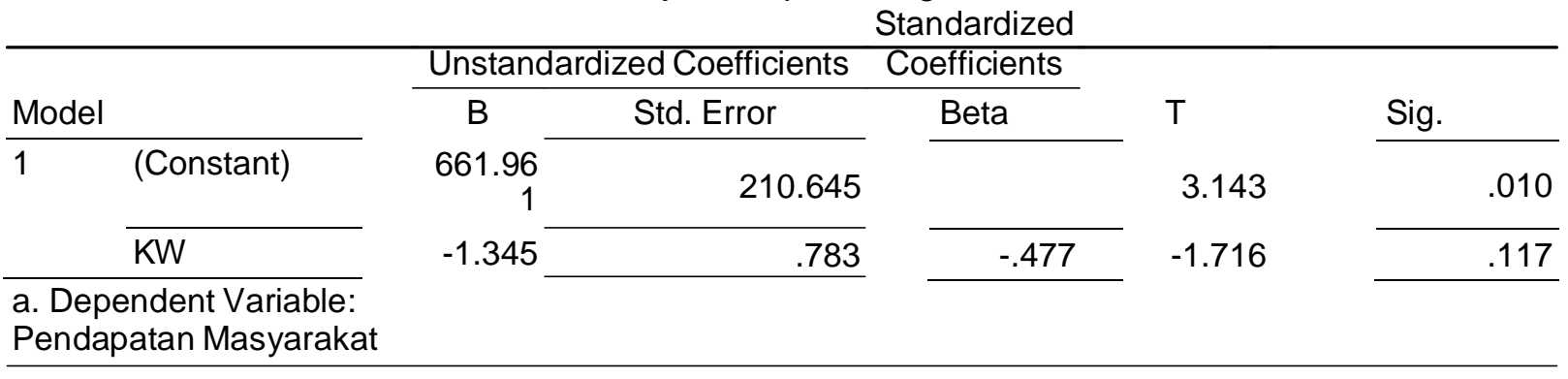

Sumber : hasil analisis regresi linier sederhana (lampiran 3)

Berdasarkan table 4.2 menunjukan bahwa variabel kunjungan wisata berpengaruh tapi tidak signifikan terhadap pendapatan masyarakat, karena nilai t hitung $=1.716>$ t tabel $=1.662$ dan $p$-value $=0.117$ $>\alpha=0.05$ maka Ho ditolak. Oleh karena itu, maka dapat disimpulkan bahwa kunjungan wisata berpengaruh tetapi tidak signifikan terhadap pendapatan masyarakat di Desa Medewi pada tahun 2016.

Berdasrkan tabel 4 pengujian hipotesis dilakukan dengan jumlah sampel 88 orang, sehingga dapat diperoleh $\mathrm{df}=\mathrm{n}-$ $k=88-2=86$, sehingga $t$ table dengan df 86 adalah sebesar 1.662 .

Tabel 5 hasil perhitungan koefisien determinasi (R2) dalam model summary

\begin{tabular}{|c|c|c|c|}
\hline Model & $\mathrm{R}$ & Adjusted R Square & Std. Error of the Estimate \\
\hline 1 & $.47^{\mathrm{a}}$ & .150 & 301.51780 \\
\hline a. Prec & (Constant) & , Kunjungan Wisata & \\
\hline
\end{tabular}

Sumber : hasil analisis Ttest

Berdasarkan tabel 4.3 besarnya nilai korelasi atau hubungan ( $R$ ) yaitu sebesar 0,477 dan dijelaskan besarnya prosentase pengaruh variabel bebas terhadap variabel terikat yang disebut koefisien determinasi yang merupakan hasil dari penguadratan $R$. Dari output tersebut diperoleh koefisien determinasi (R2) sebesar 0,228 yang mengandung pengertian bahwa pengaruh variabel bebas (kunjungan wisata) terhadap variabel terikat (pendapatan masyarakat) adalah sebesar $22,8 \%$ dan sisanya $77,2 \%$ dipengaruhioleh variabel lain.

\section{Pembahasan}

Berdasarkan hasil penelitian yang telah dilakukan mengenai pengaruh kunjungan wisata terhadap pendapatan masyarakat di Desa Medewi Kecamatan Pekutatan Kabupaten Jembrana Tahun 2016 diketahui bahwa kunjungan wisata tidak berpengaruh terhadap pendapatan masyarakat. Hal ini disebabkan oleh banyaknya masyarakat yang tidak berpatisipasi langsung dalam kegiatan pariwisata yang ada di kawasan Objek Wisata Pantai Medewi ini. Banyak masyarakat di kawasan objek wisata pantai 
Medewi ini bekerja sebagai petani, nelayan, Pegawai dan wiraswasta.

Penelitian ini sejalan dengan penelitian terdahulu oleh Novi Dwi Purwanti (2014) dengan judul Pengaruh Jumlah Kunjungan Wisatawan Terhadap Pendapatan Asli Daerah (PAD) Kabupaten Mojokerto Tahun 2006-2013. Hasil dalam penelitian ini menyebutkan bahwa berdasarkan hasil uji $\mathrm{T}$ diperoleh $\mathrm{p}$-value $=$ $0.085>\alpha=0.05$ jadi Ho diterima, yang berarti bahwa jumlah kunjungan wisatawan tidak berpengaruh terhadap Pendapatan Asli Daerah (PAD) Kabupaten Mojokerto tahun 2006-2013. Penelitian ini juga sejalan dengan penelitian terdahulu oleh Epi Syahdat dengan judul Faktor-faktor Yang Mempengaruhi Kunjungan Wisatawan di Taman Nasional Gede Pangrango (TNGP). Hasil dari penelitian ini menunjukkan bahwa faktor pelayanan, sarana prasarana, objek dan daya tarik wisata alam (odtwa) dan keamanan secara simultan berpengaruh terhadap jumlah pengunjung/wisatawan akan tetapi tidak signifikan. Dari keempat faktor tersebut hanya satu yang berpengaruh sigfnifikan yaitu faktor keamanan, sedangkan tiga faktor lainnya yaitu pelayanan, sarana prasarana dan objek dan daya tarik wisata alam (ODTWA) mempunyai pengaruh tapi tidak signifikan.

\section{PENUTUP \\ Simpulan}

Berdasarkan hasil analisis data dan pembahasan maka dapat ditarik simpulan sebagai berikut. 1) Jumlah kunjungan wisata di objek wisata pantai Medewi pada tahun 2016 adalah sebanyak 3.076 orang pengunjung. 2) Pendapatan masyarakat di Desa Medewi pada tahun 2016 dengan adanya objek wisata pantai ini adalah dari paling rendah Rp. 3.000.000,- hingga paing tinggi yaitu Rp. 21.000.000,- perbulannya. 3)Pengaruh kunjungan wisata terhadap pendapatan masyarakat dapat disimpulkan bahwa kunjungan wisata tidak berpengaruh terhadap pendapatan masyarakat di Desa Medewi Kecamatan Pekutatan Kabupaten Jembrana tahun 2016.. Hal tersebut dapat ditunjukan dari hasil analisis $\mathrm{t}$ tes yang menunjukan $p$-value $=0,117>\alpha=0,05$.

Saran

Berdasarkan simpulan diatas maka dapat dikemukakan beberapa saran sebagai berikut. 1)Bagi lembaga Undiksha. Hasil penelitian ini menunjukkan bahwa kunjungan wisata tidak berpengaruh terhadap pendapatan masyarakat di Desa Medewi Kecamatan Pekutatan Kabupaten Jembrana tahun 2016. Peneliti mengharapkan agar lembaga Undiksha juga dapat memfasilitasi mahasiswa yang ingin melakukan penelitian sejenis untuk dapat lebih baik lagi hasil yang diperoleh. 2) Bagi peneliti lain. Bagi peneliti lain yang bermaskud melakukan penelitian di bidang pendapatan khususnya tentang pengaruh kunjungan wisata, diharapkan untuk mengembangkan peneltian ini dengan menambah populasi dan sampel yang lebih luas serta menambahkan variabel bebasnya agar dapat menguji variabel lain yang diduga kuat dapat mempengaruhi pendapatan masyarakat.

\section{DAFTAR PUSTAKA}

Amanda, Meita. 2009. Analisis Dampak Ekonomi Wisata Bahari Terhadap Pendapatan Masyarakat Lokal (Studi Kasus Pantai Bandulu Kabupaten Serang Provinsi Banten). Skripsi (tidak diterbitkan), Prodi Ekonomi Sumberdaya dan Lingkungan Fak. Eko dan Manajemen IPB, Bogor.

Anonimus, 2001. Dampak Parwisata Terhadap Aspek Sosial Budaya Masyarakat Bali, Hasil Penelitian, Bali.

Anonimus, 1999. Pemasaran Pariwisata Bali, Keadaan, Analisis dan Potensi Pasar Wisata, Dinas Pariwisata Prvinsi Bali.

Gafur, Juliafitri Dj. 2008. Analisis Kontribusi Sektor Pariwisata Terhadap Pendapatan Asli Daerah Kota 
Bitung tesis (tidak diterbitkan), Medan : Universitas Sumatera Utara.

Maoleong, L.J,. 2001. Metodologi Penelitian Kualitatif. Bandung : PT. Remaja Rosdakarya.

Marpaung, Happy. 2000. Pengetahuan Kepariwisataan, Bandung : Alfa Beta

Margono, S. 1997. Metodologi Penelitian Pendidikan, Jakarta : PT. Rineka Cipta.

Muljadi, A.G., dan Andri Warman. 2014. Kepariwisataan dan Perjalanan, Jakarta : PT. Grafindo Persada.

Nazir. 1999. Metodologi Penelitian, Cetakan Keempat, Jakarta : Ghalia Indonesia.

Nawawi, H. 2001. Metodologi Peneltian Bidang Sosial, Gajah Mada University Press.

Nuryati, W., Bambang Sunaryo. 1993. Pariwisata dan Dampaknya, bahan untuk dipakai dilingkungan sendiri, Yogyakarta.

Pendit, N.S,. 1999. Ilmu Pariwisata Bali, Denpasar : Bali Post

1994. Ilmu Pariwisata Sebuah Pengantar Perdana, Jakarta : PT. Pradnya Paramita.

Pitariningtyas. $2000 . \quad$ Pengaruh Perkembangan Pariwisata Terhadap Kehidupan dan Ekonomi Masyarakat Setempat Di Kawasan Wisata Bendungan, Kolokium, Fakultas Teknik Universitas Diponogoro, Semarang.

Pitana, I Gede. 1999. Pelangi Pariwisata Bali, Denpasar : Bali Post

Prayogi, Putu Agus. 2011. Dampak Perkembangan Pariwisata Di Objek
Wisata Panglipuran, Jurnal Perhotelan dan Pariwisata, Vol.1 No.1 Hal.64, STP Triatma Jaya, Bali.

Rizal, Isahaq. 2000. Dampak Sosial Ekonomi dan Budaya Kepariwisataan Pantai Ujong Blang Lhokseumawe Provinsi Daerah Istimewa Aceh. Tesis (tidak diterbitkan), Yogyakarta.

Santosa, Purbayu Budi dan ASHARI. 2005. Analisis Statistik dengan MS Excel dan SPSS, Semarang, Penerbit Andi.

Spillane, J James. 1987. Ekonomi Pariwisata Sejarah dan Prospeknya. Yogyakarta :Kanisius.

Sunyoto, Danang. 2015. Keunggulan Bersaing. Yogyakarta : CAPS ( Center for Academic Pulishing Service ).

Wahab, Salah. 2003. Industri Pariwisata dan Peluang Kesempatan Kerja. Jakarta: PT. Pertja.

Widoyoko, Eko P. 2012. Teknik Penyusunan Instrumen Penelitian. Yogyakarta: Pustaka Belajar.

Yoeti, Oka A. 1996. Pengantar IImu Pariwisata. Bandung: PT. Angkasa. 